\title{
Use of space by neotropical marsupial Didelphis albiventris (Didelphimorphia: Didelphidae) in an urban forest fragment
}

\author{
Alex J. de Almeida; Camila G. Torquetti \& Sônia A. Talamoni \\ Conservation, Ecology and Behavior Group, Programa de Pós-graduação em Zoologia de Vertebrados, Pontifícia Universidade \\ Católica de Minas Gerais. Avenida Dom José Gaspar 500, Prédio 41, 30535-610 Belo Horizonte, Minas Gerais, Brasil. \\ E-mail: alexjosebio@gmail.com; talamoni@pucminas.br
}

\begin{abstract}
A population of the Neotropical marsupial Didelphis albiventris (Lund, 1840) living in an urban forest fragment was studied. Population structure and the influence of sex and age on two variables related to habitat use (Daily home range - MCP and Habitat use intensity - UI) obtained by the spool-and-line technique were analysed. There were 20 males and 29 females studied $(N=49)$. No sexual dimorphism was apparent in adult individuals. There were 16 males and 24 females tracked using the spool-and-line device. There were significant differences found in the mean size of the daily home range, which was greater in adults than in sub-adults. Regarding the habitat use intensity there were also significant differences related to age. There were no significant differences in MCP and UI related to the sex of the individuals. Besides the analyzed factors, the variables related to habitat use are possibly influenced by other factors, especially, the ones related to the conservation status of the fragment.
\end{abstract}

KEY WORDS. Daily home range; habitat use intensity; spool-and-line tracking; white-eared opossum.

RESUMO. Uso do espaço pelo marsupial Neotropical Didelphis albiventris (Didelphimorphia: Didelphidae) em um fragmento florestal urbano. Neste estudo foi analisada uma população do marsupial neotropical Didelphis albiventris (Lund, 1840), em um fragmento florestal urbano, e foram analisados aspectos da estrutura da população, e a influência do sexo e da idade em duas variáveis relativas ao uso do hábitat - Área de Vida Diária (MCP) e Intensidade de Uso do Hábitat (UI), obtidas com a técnica do carretel de rastreamento. Foram estudados 49 indivíduos marcados, dos quais 20 eram machos e 29 eram fêmeas. Dos animais adultos, não foi encontrado qualquer dimorfismo sexual. De 40 indivíduos rastreados com carretel (16 machos, 24 fêmeas), diferenças significativas no MCP foram encontradas, sendo que os indivíduos adultos apresentaram tamanhos médios maiores que os sub-adultos. Quanto à UI, diferenças significativas foram observadas também relacionadas à idade. Não foram encontradas diferenças entre sexos com relação ao MCP e IU. Além dos fatores analisados, as variáveis relativas ao uso do hábitat possivelmente são influenciadas por outros fatores, especialmente aqueles relacionados ao estado de conservação do fragmento.

PALAVRAS-CHAVE. Área de vida diária; carretel de rastreamento; gambá-de-orelha-branca; intensidade de uso do hábitat.

Home range has long been used in mammal studies to describe the area in which an individual forages, mates, and rears offspring (BURT 1943). Home range size varies with body size and resource availability (МсNAB 1963). Body size and its influence on home range size has been studied in small mammals (Izor \& Pine 1987, Vieira 1997, Cunha \& Vieira 2002). Today we understand that body size and energetic requirements of the species are directly related to their way of life (HARESTAD $\&$ BUNNELl 1979). Intra-population variation in home range size is also due to several factors such as sex, age, population densities, seasonality and habitat quality among others (ANDERSON \& Koopman 1981).

Daily home range as a concept has been recently used in studies with non-volant small mammals (CUNHA \& VIEIRA 2002, Mendel \& Vieira 2003, Loretto \& Vieira 2005, Vieira et al. 2005), and differs from home range in that it is an estimate of daily, and not lifetime, area use (Delciellos et al. 2006). Daily home range size can be estimated by the use of the spool-and-line technique (Miles 1976, Miles et al. 1981, Boonstra \& Craine 1986). This technique is also efficient to estimate intensity of habitat use within the daily home range (LoRetTo \& Vieira 2005). The first use of this technique was in a study of North American tortoises (BREDER 1927). Subsequently, studies using this method were limited to turtles and anurans (review in Delciellos et al. 2006), with the first use of the technique on non-volant small mammals by MiLes (1976).

Revista Brasileira de Zoologia 25 (2): 214-219, June, 2008 
The withe-eared opossum, Didelphis albiventris (Lund, 1840) (Didelphidae), is one of the South American didelphids and is a common and abundant species in the Neotropical region (CERqueira 1985). The species of Didelphis Linnaeus, 1758 usually has hight flexibility in their space use using different supports in many vertical strata (CUNHA \& VIEIRA 2002, CÁCERES 2003, CUNHA \& VIEIRA 2005). These characteristics enable the species to use several environments including those near or inside urban areas (FONSECA et al. 1982, CÁCEREs 2000). The diet is characterized as generalist, and the opossums feed on invertebrates (majority insects), plant material and small vertebrates (TALAmONI \& DiAs 1999). The white-eared opossum is a medium sized animal with a body mass varying between 500 and $2000 \mathrm{~g}$ in adult individuals (EMmons \& FeER 1997). It is a solitary and nocturnal species, mainly terrestrial but can occasionally climb trees, reaching the highest forest strata, like observed to D. aurita (CunHA \& VIEIRA 2002, 2005, LORETTO \& VIEIRA 2005). The reproduction is seasonal, with a long reproductive period starting in the southern in September at the end of the dry season and extending to March at the end of the rainy season (TAlamoni \& Dias 1999). However, the knowledge on the life history of the species is scarce, especially in highly modified environments, although the species seems to be well adapted to urban habitats (Alessio et al. 2005).

Here, we describe some aspects of the use of space use the neotropical marsupial $D$. albiventris in an urban forest fragment, using the spool-and-line technique. We investigating the influence of sex and age are related to habitat use, specifically with daily home range and habitat use intensity.

\section{MATERIAL AND METHODS}

\section{Study area}

This study was in a fragment of semideciduous forest of ca. 10 ha on the campus of the Pontific Catholic University of Minas Gerais (PUC Minas) (1955'11"S, 4359'29”W, 906 m above s.l.) in Belo Horizonte, Brazil. The fragment is entirely surrounded by urban areas and includes plants in 17 families, with Fabaceae, Myrtaceae, Euphorbiaceae, Sapindaceae and Monimiaceae being the most common (WERNECK 1998). Rainfall is seasonal, with a rainy season from October to March and a dry season from April to September.

\section{Animal captures}

Fifty live traps of $15 \times 15 \times 30 \mathrm{~cm}$ were placed along two $100 \mathrm{~m}$ transects and two $150 \mathrm{~m}$ transects in different areas of the fragment. The traps were baited with a mixture of banana, peanut butter, cod liver oil, fruit flavors and corn flour. Captured individuals were sexed, measured (body weight, body length, tail length, ear length, hidfoot length) and marked using combinations of ear perforations. Captures were monthly from June 2006 to April 2007, with a total sampling effort of 1550 traps-night.

\section{Spool-and-line tracking}

Spool-and-line tracking began in September 2006. After the capture, a spool was mounted in some individuals follow- ing the procedure originally proposed by MiLes et al. (1981) and improved by Boonstra \& Craine (1996). The device has a cocoon of nylon line coiled around itself without any reel. The line is released by a hole in one of the edges of the device which is covered with PVC film and one or two layers of masking tape and then fixed to the dorsal region of the animals (CUNHA \& VieIra 2002). Devices weighing $2 \mathrm{~g}$ (with $200 \mathrm{~m}$ of line) and 5 $\mathrm{g}(500 \mathrm{~m})$ were used depending on the weight of each individual. Each line was stained with a different color to distinguish individual tracks. One end of the line was tied to a tree near the capture location after which the individual was released and their track marked by the unwinding line. The following day the track was mapped with a compass and a measuring tape. This tracking method does not interfere with natural behavior of the animals (STEINwald et al. 2006).

Tracks were mapped by determing the compass angle of each turn and measuring the linear distance between each turn point. Subsequently, azimuths and distances were transformed to Cartesian coordinates $(\mathrm{x}, \mathrm{y})$. These coordinates were used to calculate the daily home range by calculating the area of the minimum convex polygon (MCP) that included all the points recorded (software Biotas 1.0.4 alpha). Habitat use intensity (UI) was estimated following LoretTo \& Vieira (2005) and is defined as the distance moved (line length) divided by the square root of the MCP. UI is greater when the animal moves repetitively for short distances or with more arboreal movements. Smaller values result from longer straight-line distances. Here, we only used lines that were $>35 \mathrm{~m}$ to calculate UI, following LoretTo \& Vieira (2005).

\section{Data analysis}

The intra-population variation in the daily home range and in the habitat use intensity as a function of sex and age and an interaction between these two factors was investigated using a variance analysis (ANOVA) and general linear models (GLM) (LiNDSEY 1997). Tukey's test for post hoc comparisons was used when needed. Initially the model was adjusted to explain the variation in MCP and IU values assuming the normality of log MCP and log UI values. The analysis of residues allowed the acceptance of the premise of normality of the response variable. The parametric methods for model estimation are usually sensitive to observations that can substantially vary the model, usually referred as influent (LINDSEy 1997). These observations were detected and excluded for a posterior readjustment. In this study the MCP and the UI were significantly correlated with the total amount of mapped line (MCP, $\mathrm{r}^{2}=0.6462, \mathrm{r}=0.8030, \mathrm{p}=0.0000$; UI, $\left.\mathrm{r}^{2}=0.3615, \mathrm{r}=0.6012, \mathrm{p}=0.0000\right)$. Therefore, the values of the response variable and the factors to be tested (sex, age and their interactions) were included in the models of variance analysis via GLM, using as an additional variable (covariate) the total amount of mapped line (DrAPER \& SMITH 1998). The total amount of mapped line and its interactions with the effects of the other factors were tested. A significant result indicates that the total amount of mapped line interfered with the factors tested and 
thus, the individual differences of those factors cannot be tested. If the interaction is not significant the effects of the total amount of mapped line on sex and age are not considered, and the adjustment of the model is executed again (LoRETTO \& VieIRA 2005). All the analyses were carried out using the Minitab 14.13 software with a significance level of 0.05 .

\section{RESULTS}

Forty nine white-eared opossums were marked and captured a total of 98 times (capture success $=6.32 \%$ ). Twenty marked individuals were males ( 11 sub-adults and nine adults) and 29 were females (14 sub-adults and 15 adults). All individuals weighing less than $500 \mathrm{~g}$ were captured between October and March. Total biomass of captured animals was $27.5 \mathrm{~kg}$. Sexual dimorphism was absent (Tab. I).

Forty individuals were followed with the spool-and-line and mapped during nine capture periods. The dispersal of the individuals occurred in the totality of the fragment, since their border to the center. There were $4791.72 \mathrm{~m}$ of mapped line. Between $100-200 \mathrm{~m}$ of line was mapped for $43 \%$ of the individuals and more than $200 \mathrm{~m}$ in $20 \%$ of the individuals. Males provided a total mapped distance of $1829 \mathrm{~m}$ (mean $=114.23 \mathrm{~m}$; standard error $=19.93 ; \mathrm{n}=16)$ while females provided $2964 \mathrm{~m}$ (mean = $123.49 \mathrm{~m}$; standard error $=13.80 ; \mathrm{n}=24$ ). Adults of both sexes had greater daily home range sizes than sub-adults (Fig. 1, Tab. II). Habitat use intensity was similar in both sexes and age classes (Fig. 2, Tab. II), however, adult males was somewhat greater.

The best model explaining daily home range size had a $\mathrm{r}^{2}=0.925$, while the model for IU was $\mathrm{r}^{2}=0.605$. All models including sex, age class, and amount of mapped line on estimating home range size was not significant (Tab. III). Habitat use intensity was apparently influenced by age (Tab. IV).

\section{DISCUSSION}

The exclusive presence of $D$. albiventris in the fragment at the PUC Minas is probably related to its flexibility in habitat use and to its generalist diet (Fonseca et al. 1982, TALAmONI \& DiAS 1999) that allow it to establish efficiently in disturbed environments (CÁCERES 2000). The absence of other small mammal species, together with the sporadic presence of few preda-
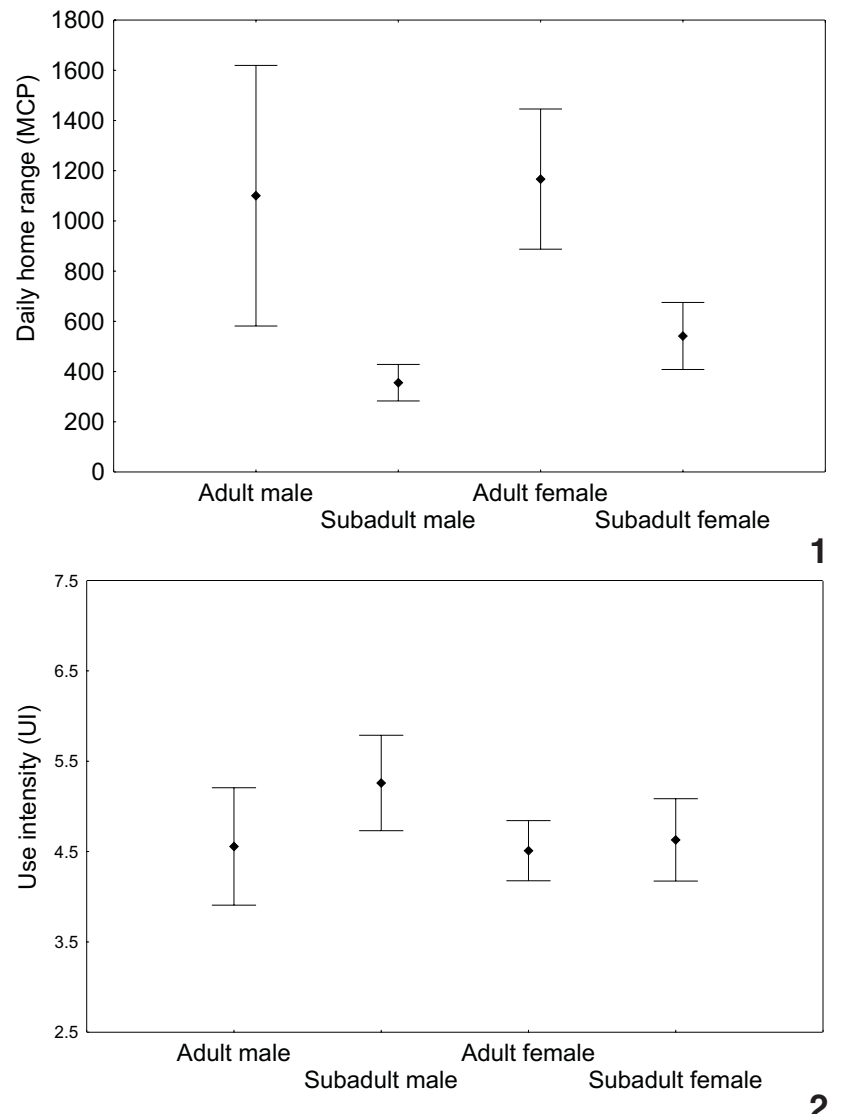

Figures 1-2. (1) Mean daily home range values (MCP in $\mathrm{m}^{2}$ ) and (2) mean habitat use intensity values (UI) and respectivally standard errors, sorted by sex and age of $D$. albiventris individuals captured in an urban forest fragment at the PUC Minas during June 2006 to April 2007.

tors (owls and domestic cats and dogs) certainly contribute (Fonseca \& Robinson 1990) to the success of this species in the fragment. This is confirmed by the high abundance and biomass levels found in the area. Academics studies have been observed the absence of another species of small mammals in the study fragment in agreement with the present work.

Table I. Measurements of the adult D. albiventris captured in an urban forest fragment at PUC Minas from June 2006 to April 2007 . The mean, standard error, minimum and maximum are shown, with number of captures. P values indicate test results for sexual dimorphism.

\begin{tabular}{|c|c|c|c|c|c|c|c|c|c|}
\hline & \multicolumn{3}{|c|}{ Male } & \multicolumn{3}{|c|}{ Female } & \multirow{2}{*}{$\mathrm{t}$} & \multirow{2}{*}{ d.f. } & \multirow{2}{*}{$P$} \\
\hline & Mean \pm S.E. & Max. - Min. & $\mathrm{N}$ & Mean \pm S.E. & Max. - Min. & $\mathrm{N}$ & & & \\
\hline Body mass (g) & $996.0 \pm 100.5$ & $1850.0-500.0$ & 15 & $948.8 \pm 63.7$ & $1700.0-520.0$ & 25 & 0.68 & 4 & 0.5286 \\
\hline Body (mm) & $285.2 \pm 19.5$ & $430.0-162.0$ & 11 & $319.4 \pm 17.9$ & $520.0-225.0$ & 20 & 1.69 & 4 & 0.1649 \\
\hline Tail (mm) & $303.5 \pm 10.7$ & $380.0-264.0$ & 10 & $320.9 \pm 11.2$ & $420.0-264.0$ & 15 & 0.88 & 4 & 0.4256 \\
\hline Hind foot $(\mathrm{mm})$ & $42.9 \pm$ & $52.1-36.9$ & 15 & $43.9 \pm 0.7$ & $52.1-36.8$ & 25 & 0.49 & 4 & 0.6472 \\
\hline Ear (mm) & $34.9 \pm$ & $42.5-28.9$ & 15 & $35.0 \pm 1.1$ & $46.6-$ & 25 & 0.34 & 4 & 0.7509 \\
\hline
\end{tabular}


Table II. Daily home range (MCP in $\mathrm{m} 2$ ) and habitat use intensity (UI) using the spool-and-line technique in an urban forest fragment at the PUC Minas from June 2006 to April 2007. The mean, standard error, minimum and maximum are shown, with number of captures.

\begin{tabular}{|c|c|c|c|c|}
\hline & \multicolumn{2}{|c|}{$\mathrm{MCP}(\mathrm{m} 2)$} & \multicolumn{2}{|c|}{ UI } \\
\hline & Mean \pm S.E. & Min.-Max. & Mean \pm S.E. & Min.-Max. \\
\hline Adult male $(\mathrm{N}=5)$ & $1100.38 \pm 519.01$ & $318.77-3047.60$ & $4.55 \pm 0.64$ & $2.49-6.23$ \\
\hline Sub-adult male $(\mathrm{N}=11)$ & $355.61 \pm 72.71$ & $105.57-824.63$ & $5.25 \pm 0.52$ & $3.53-9.52$ \\
\hline Adult female $(\mathrm{N}=12)$ & $1166.65 \pm 279.09$ & $284.23-3823.28$ & $4.50 \pm 0.33$ & $3.42-7.80$ \\
\hline Sub-adult female $(\mathrm{N}=12)$ & $541.81 \pm 133.45$ & $86.64-1744.77$ & $4.62 \pm 0.45$ & $3.47-9.12$ \\
\hline
\end{tabular}

Table III. Effect of age, sex and total amount of mapped line on the daily home range size (MCP) and habitat use intensity (UI) estimates using the spool-and-line technique for D. albiventris individuals captured in an urban forest fragment at PUC Minas from June 2006 to April 2007.

\begin{tabular}{lrrrrrr}
\hline \multirow{2}{*}{ Factor } & \multicolumn{2}{c}{ MCP } & & \multicolumn{2}{c}{ UI } \\
\cline { 2 - 3 } \cline { 6 - 7 } \cline { 6 - 7 } & \multicolumn{1}{c}{$\mathrm{F}$} & $\mathrm{p}$ & & $\mathrm{F}$ & $\mathrm{p}$ \\
\hline Sex & 2.22 & 0.1480 & & 0.06 & 0.8120 \\
Age & 7.81 & 0.0100 & & 0.01 & 0.9160 \\
Mapped line & 42.99 & 0.0000 & & 44.88 & 0.0000 \\
Sex * age & 0.03 & 0.8600 & & 0.07 & 0.8000 \\
Sex * mapped line & 3.64 & 0.0670 & & 0.73 & 0.4000 \\
Age * mapped line & 3.26 & 0.0820 & & 3.74 & 0.0620 \\
Sex * age * mapped line & 0.22 & 0.6460 & & 0.33 & 0.5690 \\
\hline
\end{tabular}

* Interaction between factors.

Table IV. Effect of sex, age and total amount of mapped line on the daily home range size (MCP) and habitat use intensity (UI) estimates using the spool-and-line technique for $D$. albiventris individuals captured in an urban forest fragment at PUC Minas from June 2006 to April 2007. Here we exclude interactions not found to be significant in table III.

\begin{tabular}{lrrrrrr}
\hline \multirow{2}{*}{ Factor } & \multicolumn{2}{c}{$\mathrm{F}$} & & \multicolumn{2}{c}{$\mathrm{UI}$} \\
\cline { 2 - 3 } \cline { 5 - 6 } \cline { 5 - 6 } Total mapped line & 140.81 & 0.0000 & & 40.23 & 0.0000 \\
Sex & 2.12 & 0.1550 & & 2.44 & 0.1270 \\
Age & 3.93 & 0.0500 & & 8.88 & 0.0050 \\
Sex * age & 0.03 & 0.8600 & & 0.65 & 0.4260 \\
\hline
\end{tabular}

* Interaction between factors.

However, the main characteristic contributing to the ecological plasticity of this species is their high reproductive efficiency (AUSTAD 1988). The high number of sub-adults captured during the rainy season suggests that the studied population is reproducing during the reproduction period already reported for this species (TALAMONI \& DiAs 1999). Usually, the reproductive success in small mammals is related to the environmental conditions (AlHo et al. 1986). In some species with seasonal reproduction associated to the period of highest rainfall the reproduction has been associated to higher resources availability (Bergallo \& Magnussom 1999). However, the reproductive strategy in Neotropical marsupials can also be determined by the photoperiod (CERQUeIRA 2005). On the other hand, CÁCERES (2000) observed a high seasonal recruitment of sub-adult individuals in forested fragments in urban environments. This author associated the high recruitment rates to a process compensating the high mortality levels of adults caused by anthropogenic factors such as road kills and fights with domestic dogs.

Additionally, the ability to adjust the sex ratio of offspring by varying parental care, as observed for for species of Didelphis (Austad 1988, Sunquist \& EIsEnberg 1993), may contribute to the success of opossums, which may explain the female bias in the sex ratio. In the studies above mentioned it was observed that reproductively active animals that received food supplements produced more males. Also, higher rates of parental care by the reproducing females shifted the sex ratio towards males (AUSTAD 1988). Thus, it is believed that in environments with more food availability females have greater energy supplies and can display higher levels of parental care. In consequence, a higher number of males are expected in the population, probably to increase their dispersion in the environment.

In the present study the food availability was not measured. However, considering the small size of the fragment and the high anthropic pressure surrounding it, we believe that food supplies are limited. Thus, the skewed sex ratio observed of 1.45 females for each marked male can be reflecting this sophisticated reproductive strategy. Assuming limited food availability in anthropized environments it could be that parental care is restricted as a consequence of this limited food availability, resulting in the observed higher numbers of females. Experiments directed to prove this hypothesis should be made before specific conclusions about this phenomena in the study area can be determinated. On the other hand, the sexual ratio deviation for females could result of a characteristic of the capture method. In the reproduction season, adult males disperses more than females to get sexual partnership and then can be their capturability decreased (CÁCEREs 2003).

Body size differences between sexes in species of Didelphis have been observed (Petrides 1949, Gardner 1973, Tyndale-Biscoe \& Mackenzie 1976, Fonseca \& KierulfF 1989, Cherem et al. 1996). 
No sexual dimorphic character was observed in this study relative to the biometric parameters measured, as opposed to the findings of TALAMONI \& DiAs (1999) that observed dimorphism in adult individuals regarding body mass and body and foot length, and Richard-HANSEN et al. (1999) that found the tail length to be a dimorphic character. CÁCERES \& MONTEIRO-FilHo (2001) registred a sex ratio deviation in the adults head length, although in this study those corporal parameter were not sampled.

Dimorphism could be associated to significant differences in daily home ranges and in habitat use intensity between sexes, since marked dimorphisms could, among others, indicate ecological niche separations between sexes (SHINE 1989, CÁCERES \& Monteiro-Filho 2001). However, variations in habitat use are not only influenced by dimorphism and could be dependent of other factors (ANDERSOn \& KoOpMAn 1981, SwiHART et al. 1988) such as seasonality effects (LoretTo \& VIEIRA 2005) that were not evaluated during this study.

The differences found in the mean daily home range (MCP) for sub-adult and adult $D$. albiventris individuals of the same sex were statistically confirmed by the model used in the analysis of the generalized linear models. These differences can probably reflect the energetic requirements of each individual, a fact usually related to the energetic requirements of species with different body mass (Harestad \& Bunnell 1979, GitTleman \& HaRvey 1982).

Regarding the significant differences in habitat use intensity (UI) between different age classes, this probably resulted because of the higher mean observed in sub-adult males. However, this result cannot be directly related to the situation described by CunHa \& VieIra (2005). These authors observed that D. aurita individuals of all age classes used the vertical stratum but that young individuals used it more frequently, and the differential use made by young individuals can be associated with efficient routes to escape from predators since it has been observed in $D$. virginiana that young individuals have higher rates of mortality by predation (HossLer et al. 1994). The most accepted hypothesis proposes that young individuals are not as efficient as adult individuals when escaping predators on the ground. Moreover, young individuals have smaller sizes and thus, can quickly reach higher vertical stratum (CunHa \& VieIRA 2005). However, it is worth to remember that higher UI values represent not only the use of the vertical dimension but also a more intensive use of the ground in smaller daily home ranges.

Besides the factors discussed above, it is also known that population density (ABRAMSKY \& Tracy 1980), distribution (Joshi et al. 1955), food abundance (Mares et al. 1982), and predation risk (Longland \& Prince 1991) also interfere in the way of life of the individuals. Therefore, considering the peculiar conditions of the studied area (i.e. the high opossum abundance, the absence of other small mammal species, the small size of the fragment and the urban surroundings of it) is important to consider that all these factors might be affecting the daily home range and the habitat use intensity of the studied individuals.

\section{ACKNOWLEDGMENTS}

To Marcus V. Vieira, Diogo Loretto, Dartagnan L. Viana, Gilmar B. dos Santos, Robert J. Young and Adriano Paglia for their help and suggestions. To Raíssa Araújo for her very important help during data collection. To the Brazilian Environmental Office (IBAMA) for issuing the license \#044/05-NUFAS/ MG, and to PROBIC/FAPEMIG by the scientific initiation fellowship given to first author.

\section{LITERATURE CITED}

Abramsky, Z. \& C.R. Tracy. 1980. Relation between home ranges size and regulation of population size in Microtus ochrogaster. Oikos 34: 347-355.

Alessio, F.M.; A.R.M. Pontes \& V.L. Silva. 2005. Feeding by Didelphis albiventris on tree gum in the northeastern Atlantic forest of Brazil. Mastozoologia Neotropical 12 (1): 53-56.

Alho, C.J.R.; L.A. Pereira \& A.C. Paula. 1986. Patterns of habitat utilization by small mammal populations in cerrado biome of central Brazil. Mammalia 50 (4): 447-460.

Anderson, S. \& K.F. Koopman. 1981. Does interspecific competition limit the sizes of ranges of species? American Museum Novitates 2716: 1-10.

Austad, S.N. 1988. The Adaptable Opossum. Scientific American 258 (2): 54-59.

Bergallo, H.G. \& W.E. Magnusson. 1999. Effects of climate and food availability on four rodent species in southeastern Brazil. Journal of Mammalogy 80: 472-486.

Boonstra, R. \& T.M. Craine. 1986. Natal nest location and small mammal tracking with a spool and line technique. Canadian Journal of Zoology 64: 1034-1036.

BREDER, R.B. 1927. Turtle trailing: a new technique for studying the life habits of certain Testudinata. Zoologica 9: 231-243.

BurT, H.W. 1943. Territoriality and home range concepts as applied to mammals. Journal of Mammalogy 24: 346-352.

CÁCERES, N.C. 2000. Population ecology and reproduction of the white-eared opossum Didelphis albiventris (Mammalia, Marsupialia) in an urban environment of Brazil. Ciência e Cultura 52 (3): 171-174.

CÁceres, N.C. 2003. Use of the space by the opossum Didelphis aurita Wied-Newied (Mammalia, Marsupialia) in a mixed forest fragment of southern Brazil. Revista Brasileira de Zoologia 20: 315-322

CÁceres, N.C. \& E.L.A. Monteiro-Filho. 2001. Food habits, home range and activity of Didelphis aurita (Mammalia: Marsupialia) in a forest fragment of southern Brazil. Studies on Neotropical Fauna and Environment 36: 85-92.

Cerqueira, R. 1985. The distribution of Didelphis in South America (Polyprotodontia, Didelphidae). Journal of Biogeography 12: 135-145.

Cerqueira, R. 2005. Fatores ambientais e a reprodução de marsupiais e roedores no leste do Brasil. Arquivos do Museu Nacional do Rio de Janeiro 63 (1): 29-39. 
Cherem, J.J.; M.E. Graipel; M.E. Menezes \& M. Soldateli. 1996. Observações sobre a biologia do gambá (Didelphis marsupialis) na Ilha de Ratones Grande, Estado de Santa Catarina, Brasil. Biotemas 9 (2): 47-56.

Cunha, A. \& M.V. Vieira. 2002. Support diameter, incline, and vertical movements of four didelphid marsupials in the Atlantic Forest of Brazil. Journal of Zoology 258: 419-426.

Cunha, A. \& M.V. Vieira. 2005. Age, season, and arboreal movements of the opossum Didelphis aurita in an Atlantic rain forest of Brazil. Acta Theriologica 50: 551-560.

Delciellos, A.C.; D. Loretto \& M.V. Vieira. 2006. Novos métodos no estudo da estratificação vertical de marsupiais neotropicais. Oecologia Brasiliensis 10 (2): 135-153.

Draper, N.R. \& H.A. Smith. 1998. Applied Regression Analysis. New York, John Wiley \& Sons Incorporation, III+705p.

Emmons, L.H. \& F Feer.1997. Neotropical Rainforest mammals: a field guide. Chicago, University of Chicago Press, $2^{\text {nd }}$ ed., II+307p.

Fonseca, G.A.B. \& M.C.M. KierulfF. 1989. Biology and natural history of Brazilian Atlantic forest mammals. Bulletin Florida State Museum 34 (3): 99-152

FonsecA, G.A.B. \& J.G. Robinson. 1990. Forest size and structure: Competitive and predatory effects on small mammal communities. Biological Conservation 53: 265-294.

Fonseca, G.A.B.; K.H. Redford, \& L.A. Pereira. 1982. Notes on Didelphis albiventris (Lund, 1841) of Central Brazil. Ciência e Cultura 34 (10): 1359-1362.

Gardner, A.L. 1973. The systematics of the genus Didelphis (Marsupialia: Didelphidae) in North and Middle America. Special Publications Texas Tech University 4: 1-81.

Gittleman, J.L. \& P.H. Harvey. 1982. Carnivore home-range size, metabolic needs and ecology. Behavioral Ecology and Sociobiology 10: 57:63.

Harestad, A.S. \& F.L. Bunnel. 1979. Home range and body weight - a reevaluation. Ecology 60: 389-402

Hossler, J.R.; J.B. Mcaninch \& J.D. Harder. 1994. Maternal denning behavior and survival of juveniles in opossums in southeastern. Journal of Mammalogy 75: 60-70.

Izor, R.J. \& R.H. PIne. 1987. Notes on the Black-Shouldered opossum, Caluromysiops irrupta. Fieldiana Zoology, New Series, 39: 117-124.

Joshi A.R.; J.L.D. Sмith \& F.J. CUthbert. 1955. Influence of food distribution and predation pressure on spacing behavior of palm civets. Journal of Mammalogy 76: 1205-1212.

LINDSEY, J.K. 1997. Applying generalized linear models. New York, Springer, 255p.

Longland, W.S \& M.V. Price. 1991. Direct observation of owls and heteromyids rodents: can predation risk explain microhabitat use? Ecology 72: 2261: 2273.

Loretto, D. \& M.V. Vieira. 2005. The effects of reproductive and climatic seasons on movements in the black-eared opossum (Didelphis aurita Wied-Neuwied, 1826). Journal of Mammalogy 86 (2): 287-293.
Mares, M.A.; T.E. Lacher Jr; M.R. Willig; N.A. Bitar; R. Adams; A. Klinger \& D. TAZIK. 1982. An experimental analysis of social spacing in Tamias striatus. Ecology 63: 267-273.

MCNAB, B.K. 1963. Bioenergetics and the determination of home range size. The American Naturalist 97: 133-140.

Mendel, S.M. \& M.V. Vieira. 2003. Movement distances and density estimation of small mammals using the spool-andline technique. Acta Theriologica 48: 298-300.

Miles, M.A. 1976. A simple method of tracking mammals and locating triatomine vectors of Trypanosoma cruzi in Amazonian forest. The American Journal of Tropical Medicine and Hygiene 25 (5): 671-674.

Miles, M.A.; A.A. De Souza \& M.M. Povoa. 1981. Mammal tracking and nest location in Brazilian forest with an improved spool-and-line device. Journal of Zoology 195: 331-347.

Petrides, G.A. 1949. Sex and age determination in the opossum. Journal of Mammalogy 30 (4): 364-378.

Richard-Hansen, C.; J.-C Vié; N. Vidal \& J. Kéravec. 1999. Body measurements on 40 species of mammals from French Guiana. Journal of Zoology 247: 419-428.

SHINE, R. 1989. Ecology causes for the evolution of sexual dimorphism: a review of the evidence. Quarterly Review of Biology 64 (4): 419-461.

SteinWald, M.C.; B.J. Swanson \& P.M. Waser. 2006. Effects of spool-and-line tracking on small desert mammals. The Southwestern Naturalist 51 (1): 71-78.

SunQuist, M.E. \& J.F. EISENBERG. 1993. Reproductive strategies of female Didelphis. Biological Sciences 36 (4): 109-140.

Swihart, R.; N.A. Slade \& B.J. Bergstrom. 1988. Relating body size to the rate of home range use in mammals. Ecology 69: 393-399.

Talamoni, S.A. \& M.M. Dias. 1999. Population and community ecology of small mammals in southeastern Brazil. Mammalia 63 (2): 167-181.

Tyndale-Biscoe, C.H. \& R.B. Mackenzie. 1976. Reproduction in Didelphis marsupialis and D. albiventris in Colombia. Journal of Mammalogy 57 (2): 249-265.

Vieira, E.M.; G.. Iob; D.C. Briani \& A.R.T. Palma. 2005. Microhabitat selection and daily movements of two rodents (Necromys lasiurus and Oryzomys scotti) in Brazilian Cerrado, as revealed by a spool-and-line device. Mammalian Biology 70 (6): 359-365.

Vieira, M.V. 1997. Body size and form in two neotropical marsupials, Didelphis aurita and Philander opossum (Marsupialia, Didelphidae). Mammalia 61: 245-254.

WERNECK, M.S. 1998. Comparação entre dois métodos para análise florística e estrutura de um trecho de floresta mesófila da mata da PUC Minas, Belo Horizonte - MG. Bios 6 (6): 21-31.

Submitted: 26.IX.2007; Accepted: 06.VI.2008.

Editorial responsibility: Lena Geise

Revista Brasileira de Zoologia 25 (2): 214-219, June, 2008 